\title{
The Mussel Mytilus galloprovincialis Lamarck, 1819 (Bivalvia Mytilidae) a bioindicator of metallic pollution on the Algerian West coasts
}

\author{
Tires Hachemi* \& Hebbar Chafika
}

Laboratoire d'Ingénierie en Sécurité Industrielle et Développement Durable/ Département de sécurité industrielle et Environnement / Institut de maintenance et de sécurité industrielle / Université d'Oran 2/ Mohamed Ben Ahmed / B.P N¹70, El M’Naouer-31000 Oran-Algérie.

${ }^{*}$ Corresponding author, e-mail: tires.hachemi@univ-oran2.dz

\begin{abstract}
The current work aims to study the metallic contamination of two targeted sampling sites located near the main effluent discharge points on the Algerian coasts: the industrial Gulf of Arzew (Polluted Site: S1) and Oued Elma Kristel (Reference Site: S2), using a metallic pollution indicator biological species Mytilus galloprovincialis Lamarck, 1819 (Bivalvia Mytilidae), collected at a depth of 2 to $3 \mathrm{~m}$ seasonally in 2016. Concentrations of metals and metallic indices of the trace elements (Lead, Zinc, Nickel, Iron and Copper) obtained in the soft tissues of the mussel are determined and related to the seasons and sampling sites of the current year. In site S1, the statistical study revealed significant contamination by Nickel $\left(67.63-70.28 \mathrm{mg} \cdot \mathrm{kg}^{-1}\right)$, Iron (118.18-125.45 mg.kg-1) and Copper (6.11-6.62 mg.kg-1) in summer, Zinc (213.39- 255.33 mg. $\left.\mathrm{kg}^{-1}\right)$ in winter and Lead $\left(7.55-8.78 \mathrm{mg} . \mathrm{kg}^{-1}\right)$ in autumn. However, site S2 recorded high levels of Lead (8.36-37.63 mg.kg-1) and Zinc (67.03-405.37 mg. $\left.\mathrm{kg}^{-1}\right)$ during the year.
\end{abstract}

KEY WORDS Algerian western coasts; Bioaccumulation; Bioavailability; Heavy metals; Marine pollution; Mytilus galloprovincialis.

Received 20.11.2020; accepted 18.06.2021; published online 14.09.2021

\section{INTRODUCTION}

Recently, several studies have been carried out on heavy metal contamination at local, regional and global levels. Their presence in the marine environment presents a risk for the food chain (Szefer et al., 2004; Maanan, 2008). The sea is the main outlet for effluents from the city of Oran (Taleb \& Boutiba, 2007) and the Arzew industrial gulf. This results in some contamination of the waters of fishing ports. The consequences of this pollution can be fatal, knowing that it is located near the fishing and shell collection points, even if they remain limited, hence the interest of assessing the level of contamination by certain metals toxic in the mussel Mytilus galloprovincialis Lamarck, 1819 (Bivalvia Mytilidae) collected from industrial site of Arzew and Kristel bay.

In 1983, Goldberg and his collaborators proposed quantitative monitoring of micronutrients in coastal waters with mussels (Goldberg et al., 1983). Mytilus galloprovincialis, a good species indicative of metal pollution (Guendouzi et al., 2018; Andral et al., 2011) is endowed with several positive properties: easy collection, sedentarity, wide spatial distribution, and bio accumulator of trace metals (Dang et al., 2015).

Surveillance programs have used indigenous populations for passive bio monitoring of wild 
mussels that are more sensitive to the accumulation of contaminants in their tissues following prolonged exposure (Martínez-Gómez et al., 2017). The genus Mytilus Linnaeus, 1758 has been used worldwide in bio-surveillance work, such as "Mussel Watch" (Goldberg et al., 1983), "National Observation Network (RNO Mytilus galloprovincialis)" and "Biological Integrating Network (RINBIO)" (Andral et al., 2004). The studies by Thebault et al. (2008) and those of Fowler (2002) have shown that the International Commission for the Scientific Exploration of the Mediterranean Sea (CIESM) has developed and implemented a "surveillance of Mediterranean mussels" (MMW) "in the early 2000". Several Algerian works have discussed the use of the Mytilus galloprovincialis mussel as a bio indicator species for trace metals in their Mediterranean coasts (Andral et al., 2011; Benali et al., 2015; Rouane-Hacene et al., 2015; Guendouzi et al., 2018).

The principal objective of the present study is to make a preliminary analysis of the metal pollution of Arzew industrial gulf and Kristel bay, by ex- amining the seasonal and annual variations of the concentrations and metal indices present in the chair of the Mytilus galloprovicialis. The second aim of this research is to know the main sources of this pollution by the heavy metals studied $(\mathrm{Pb}, \mathrm{Zn}, \mathrm{Ni}$, $\mathrm{Fe}$ and $\mathrm{Cu}$ ).

\section{MATERIAL AND METHODS}

\section{Study area}

The sampling sites are industrial gulf of Arzew (S1) and Oued Elma Kristel bay (S2) (Fig. 1). The first site (S1:35 $\left.48^{\prime} 43.1^{\prime \prime} \mathrm{N} / 0^{\circ} 15^{\prime} 49.0^{\prime \prime} \mathrm{W}\right)$ is located in the city of Bethioua of the industrial site of Arzew, from which several points of discharge from various factories and petrochemical industry are discharged daily into the sea without any treatment. The second site $\left(\mathrm{S} 2: 35^{\circ} 49^{\prime} 03.66^{\prime} \mathrm{N}, 0^{\circ} 28^{\prime} 55.89^{\prime} \mathrm{W}\right)$, reference site with high agricultural activity, is located east of the bay of Oran, $26 \mathrm{~km}$ from the area Arzew and near a fishermen village.

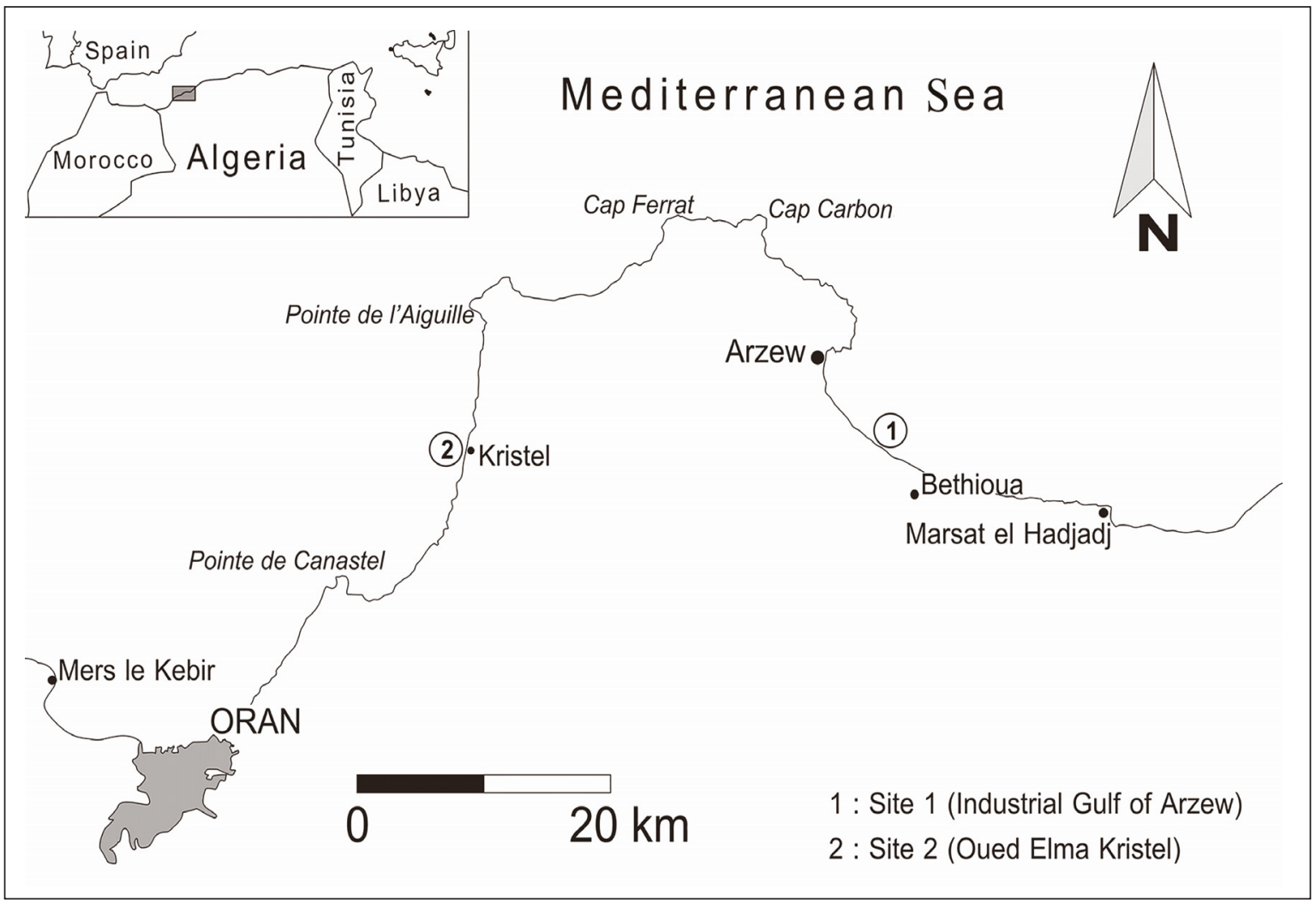

Figure 1. Geographical location of the sampling stations on the western coast of Algeria. 


\section{Samples}

Coastal water and mussel samples are collected in 2016, once per season during an annual cycle: February (winter season), May (spring season), August (summer season), and November (fall season). Sea Water samples are collected by hand in several bottles according to analytical specificities and transported in a cooler at $+4{ }^{\circ} \mathrm{C}$. The mussel specimens sampled according to the techniques counselled by QUASIMEME (Wells, 1994) are immediately washed with seawater and transferred at $+4{ }^{\circ} \mathrm{C}$ in a cooler to the laboratory for analysis. The mussels are inspected and the dead species are eliminated. Fifty individuals with different sizes (between $1.19 \mathrm{~cm}$ and $18.98 \mathrm{~cm}$ ) were used for trace metal analysis. Each mussel was opened with a stainless steel blade and placed under its ventral edge on filter paper to take out the internal water. Subsequently, the total wet weight of each individual and the soft wet weight are measured after dissection of each organism. The biometric measurements are performed on all sampled mussels and their entire soft tissues are grouped into ten pools (each pool corresponds to five individuals of identical size) and dried in a thermostatically controlled oven at 70 ${ }^{\circ} \mathrm{C}$ for $48 \mathrm{~h}$ for possible metals analyzes traces (Rouane-Hacene et al., 2015).

\section{Environmental parameters}

The physicochemical parameters of the environment such as temperature, $\mathrm{pH}$, salinity, conductivity and dissolved oxygen of the seawater are recorded in situ in all the sites by means of the multi parameter device, in parallel that the mussels were sampled. Other parameters (Phosphates, Kjeldahl nitrogen, SM, BOD5, COD, Total hydrocarbons) are analyzed in the laboratory.

\section{Metallic analysis}

The concentrations of lead $(\mathrm{Pb})$, zinc $(\mathrm{Zn})$, nickel $(\mathrm{Ni})$, iron $(\mathrm{Fe})$ and copper $(\mathrm{Cu})$ are measured in the soft tissues of mussels after the hot mineralization of the samples, according to the recommended process by Aminot \& Chaussepied (1983). About 0.25 $\mathrm{g}$ of dry weight was dissolved in $4 \mathrm{ml}$ of concentrated nitric acid at $95^{\circ} \mathrm{C}$ for 1 hour.

The metal concentration of the acid solutions is determined using a flame atomic absorption spectrophotometer (Analyst-100 Spectrophotometer, version 1.10). Assurance and quality control are evaluated by processing standard samples and reference material (Mussel Tissue Standard Reference Material SRM 2976, National Institute of Standards and Technology).

\section{Metallic indices in mussels Mytilus gallopro- vincialis}

The biological availability of metals is determined by the calculation of metal indices (MI) represented by the ratio: Metal / dry weight of the shell according to the recommended process by Soto et al. (1997) and Fischer (1984) as follows:

$$
\text { MSWI }=\text { MCSB } \times(\text { SFWD/SDW })
$$

MSWI: Metal/shell weight index (mg / kg dry weight of the shell)

MCSB: Metal concentration in soft body ( $\mathrm{mg} / \mathrm{kg}$ dry weight of the shell)

SFWD: Soft flesh dry weight ( $g$ dry weight of tissue) SDW: Shell dry weight (g).

\section{Statistical analysis}

All measurements are tested by bidirectional variance analysis (ANOVA) to detect the variability of the site or of the season. Significant differences are found at the $p<0.05$ threshold using the Tukey test for the comparison of multiple range between pairs of means, and data were tested for normality using Shapiro-Wilk test and homogeneity of variance using Levene's test. The results are represented by the mean \pm Standard Error ( $\mathrm{SE} \pm$ mean). Statistical analysis is performed using Statistica software (Statsoft Statistica 12).

\section{RESULTS AND DISCUSSION}

\section{Physico-chemical parameters of seawater}

The results of the physicochemical parameters of the seawater of each of the two sites (Arzew industrial site (S1) and Oued Elma Kristal site (S2) recorded during the four seasons of 2016, as annual average is shown in Table 1.

The annual average $\mathrm{pH}$, temperature and salinity of the surface waters obtained for these two sites are similar to those recorded in the Mediterranean Sea (Rouane-Hacene et al., 2015; Borghini et al., 2014; Iorga \& Lozier, 1999). 


\begin{tabular}{|c|c|c|c|c|}
\hline Parameters & Site 1 & Site 2 & Analysis Method & P-Value \\
\hline Temperature $\left({ }^{\circ} \mathrm{C}\right)$ & $\begin{array}{c}24.16 \pm 1.22 \\
(18.90-31.00)\end{array}$ & $\begin{array}{c}22.73 \pm 0.93 \\
(18.50-29.00)\end{array}$ & multi parameter device & $\mathrm{ns}$ \\
\hline $\mathbf{p H}$ & $\begin{array}{c}7.86 \pm 0.11 \\
(7.00-8.50)\end{array}$ & $\begin{array}{c}7.53 \pm 0.06 \\
(7.10-7.80)\end{array}$ & multi parameter devicc & ns \\
\hline Suspended matter $(\mathrm{mg} / \mathrm{L})$ & $\begin{array}{l}32.93 \pm 4.89^{\mathrm{a}} \\
(9.40-52.00)\end{array}$ & $\begin{array}{l}11.56 \pm 0.36^{\mathrm{ab}} \\
(9.23-13.58)\end{array}$ & Filtration of effluents & $* *$ \\
\hline BOD5 (mg/L) & $\begin{array}{c}27.75 \pm 1.21^{\mathrm{a}} \\
(20.00-35.00)\end{array}$ & $\begin{array}{c}29.17 \pm 0.56^{\mathrm{a}} \\
(25.00-32.00)\end{array}$ & 5-Day BOD Test & $*$ \\
\hline $\operatorname{COD}(\mathrm{mg} / \mathrm{L})$ & $\begin{array}{c}73.17 \pm 4.50 \\
(59.00-102.00)\end{array}$ & $\begin{array}{c}69.42 \pm 3.65 \\
(48.00-92.00)\end{array}$ & Spectrometry & ns \\
\hline Phosphate (mg/L) & $\begin{array}{c}1.17 \pm 0.13 \\
(0.20-1.80)\end{array}$ & $\begin{array}{c}0.64 \pm 0.13 \\
(0.12-1.45)\end{array}$ & Spectrophotometry & ns \\
\hline Kjeldahl nitrogen (mg/L) & $\begin{array}{l}0.33 \pm 0.04^{\mathrm{a}} \\
(0.19-0.59)\end{array}$ & $\begin{array}{l}0.91 \pm 0.14^{\mathrm{a}} \\
(0.22-1.88)\end{array}$ & $\begin{array}{c}\text { Oxidation of potassium } \\
\text { persulfate }\end{array}$ & * \\
\hline $\begin{array}{c}\text { Total Hydrocarbon } \\
\text { (mg/L) }\end{array}$ & $\begin{array}{l}24.33 \pm 0.58^{a b} \\
(22.00-29.00)\end{array}$ & $0.00 \pm 0.00$ & $\begin{array}{l}\text { Liquid-liquid } \\
\text { extraction }\end{array}$ & $* *$ \\
\hline Salinity (PSU) & $\begin{array}{c}36.83 \pm 0.88^{a} \\
(31.86-41.11)\end{array}$ & $\begin{array}{c}36.24 \pm 0.51^{a} \\
(32.61-38.69)\end{array}$ & multi parameter device & $*$ \\
\hline Dissolved oxygen (mg/L) & $\begin{array}{l}1.73 \pm 0.47^{\mathrm{a}} \\
(0.68-4.89)\end{array}$ & $\begin{array}{l}0.72 \pm 0.05^{\mathrm{ab}} \\
(0.25-0.90)\end{array}$ & multi parameter device & $* *$ \\
\hline Conductivity $(\mu \mathrm{s} / \mathrm{cm})$ & $\begin{array}{c}55900.90 \pm 511.96 \\
(51478.00- \\
58146.47)\end{array}$ & $\begin{array}{c}53832.23 \pm 520.39 \\
(51987.20-56789.00)\end{array}$ & multi parameter device & ns \\
\hline
\end{tabular}

Table 1. Annual variations of physico-chemical parameters of coastal waters in Industrial gulf of Arzew (S1) and Bay of Oued Elma Kristel (S2). Limit values of seasonal means are in brackets $(n=3)$. For each parameter, different letters $(\mathrm{a}-\mathrm{c})$ indicate significant differences (Tukey's test, $p<0.05$ ), among sites. Levene's Test for Homogeneity of variance, Degrees of freedom for all F's: 1.22 (ns : Non-significant; $*$ : $<0.05 ; * *: \mathrm{p}<0.001$ ).

The average concentration of total hydrocarbons recorded is too high $(\mathrm{p}<0.05)$ throughout the sampling year $(24.33 \pm 0.58 \mathrm{mg} / \mathrm{L}, \mathrm{p}<0.05)$. The Kjeldahl nitrogen values recorded at the $\mathrm{S} 1$ site are significantly lower, with an annual mean of $(0.33 \pm$ $0.04 \mathrm{mg} / \mathrm{L}, \mathrm{p}<0.05)$. Otherwise, at site $\mathrm{S} 2$, the value of Kjeldahl nitrogen increases considerably in autumn $(1.24 \pm 0.02 \mathrm{mg} / \mathrm{L}, \mathrm{p}<0.05)$, in the spring $(0.76$ $\pm 0.09 \mathrm{mg} / \mathrm{L} ; \mathrm{p}<0.05)$ and in summer $(1.37 \pm 0.27$ $\mathrm{mg} / \mathrm{L}, \mathrm{p}<0.05)$, and decreases during the winter season $(0.25 \pm 0.01 \mathrm{mg} / \mathrm{L}, \mathrm{p}<0.05)$.

The $\mathrm{pH}$ values recorded in both sites are approximate at the values appropriate of $\mathrm{pH}$ for the development of marine life (Bliefert \& Perraud, 2001). The hydrogene potential affects the toxicity of heavy metals by limiting their availability (Neff, 2002). In 2018, the work of Azizi et al. (2018) confirm that metals become more toxic as gradually as the salt content in water decreases. Dissolved oxygen comes principally from the atmosphere and photosynthesis of algae and aquatic plants. The presence of suspended solids reduces dissolved oxygen and sensitive marine species may be disturbed by an oxygen content of less than $4 \mathrm{mg} / \mathrm{L}$ (IBGE, 2005). The average values recorded at the two sites during the four seasons are below this value (4 $\mathrm{mg} / \mathrm{L}$ ).

The physicochemical parameters of water vary from one season to another, state the bioavailability of pollutants and thus influence both their bioaccumulation and the biological responses of marine organisms to them.

\section{Metallic concentrations in mussels tissue Mytilus galloprovincialis}

Figure 2 corresponds to the annual contents of the variable concentrations of metals $(\mathrm{Pb}, \mathrm{Zn}, \mathrm{Ni}$, $\mathrm{Fe}, \mathrm{Cu}$ ) in the soft tissues of our biological material (mussel), expressed in $\mathrm{mg} / \mathrm{kg}$ of dry weight, of the 


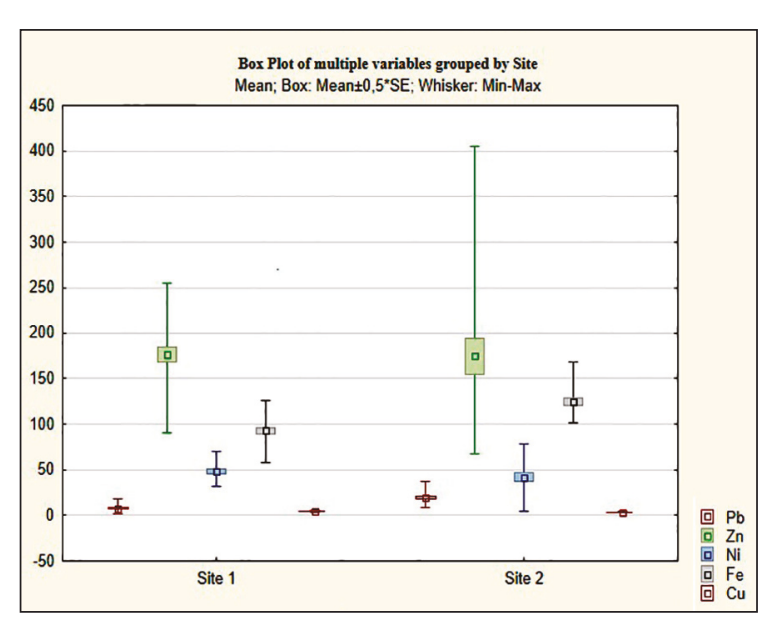

Figure 2. Annual variations of heavy metal concentrations in mussels, Mytilus galloprovincialis, from Industrial gulf of Arzew (S1) and Bay of Oued Elma Kristel (S2).

two sites S1 and S2. According to the results obtained from our sampling, it is possible to classify the bioaccumulation capacity of the mussels according to the nature of the metal, regardless of the sampling site in the following order: $\mathrm{Zn}>\mathrm{Fe}>\mathrm{Ni}>\mathrm{Pb}>\mathrm{Cu}$.

Seasonal variations in metal concentrations are presented in Table 2. The lead concentration in mussels at site S1 reached the highest level in autumn (13.64 $\pm 2.26 \mathrm{mg} . \mathrm{kg}^{-1}$ dry weight; $\left.\mathrm{p}<0.05\right)$, as well as in winter and spring $(7.52 \pm 1.33$ and $8.19 \pm 0.36$ mg.kg ${ }^{-1}$ dry weight, $p<0.05$, respectively). The highest concentrations of lead are marked in site $\mathrm{S} 2$ mussels in winter and spring $(22.93 \pm 1.03$ and $35.69 \pm 1.51$ mg.kg-1 dry weight, $\mathrm{p}<0.05$, respectively).
In both sites, lead concentrations decreased significantly over the summer $(\mathrm{p}<0.05)$. These results are similar to the results already obtained in 2015 in two other sites in western Algeria, namely 9.75 mg.kg-1 dry weight of mussels tissue from the Kristel site (Benali et al., 2015) and $10.67 \mathrm{mg} \cdot \mathrm{kg}^{-1}$ dry weight of mussels tissue from the port of Oran (Rouane-Hacene et al., 2015) and in Spain with a content of $57.83 \mathrm{mg} \cdot \mathrm{kg}^{-1}$ dry weight of mussels tissue of Cartagena (González-Fernández et al., 2015). These lead levels greater than $3.2 \mathrm{mg} . \mathrm{kg}^{-1}$ indicate marked pollution (Cantillo, 1998). A higher concentration of lead in the aquatic environment is attributed to several factors: the use of petroleum products for the manufacture of mechanized vessels, industrial effluents and sewage effluents (Muduli \& Nayak, 2018).

For Zinc, the soft tissues of Mytilus galloprovincialis showed strong seasonal variations $(\mathrm{P}$ $<0.05$ ). Mean maximum $\mathrm{Zn}$ concentrations were observed during winter at both $\mathrm{S} 1$ and $\mathrm{S} 2$ sites $\left(234.60 \pm 12,11\right.$ and $390.22 \pm 12.56 \mathrm{mg} \cdot \mathrm{kg}^{-1}$ dry weight, $\mathrm{p}<0.05$, respectively). These concentrations coincide with the results obtained at the port of Oran in western Algeria (Benali et al., 2015; Hadj et al., 2012) and those obtained in 2015 in Spain by González-Fernández and his collaborators (González-Fernández et al., 2015).

The work of Azizi et al. (2018) on the Moroccan Mediterranean coasts and those of Benali et al. (2015) on the Algerian Mediterranean coasts indicate that seasonal concentrations in metals seem

\begin{tabular}{|c|c|c|c|c|c|c|}
\hline Sites & Seasons & $\mathbf{P b}$ & $\mathbf{Z n}$ & $\mathbf{N i}$ & $\mathbf{F e}$ & $\mathbf{C u}$ \\
\hline \multirow{7}{*}{ Site 1} & Autumn & $13.64 \pm 2.26^{\mathrm{a}}$ & $207.28 \pm 2.20^{\mathrm{a}}$ & $35.33 \pm 1.05^{\mathrm{a}}$ & $102.58 \pm 1.44^{\mathrm{a}}$ & $4.56 \pm 0.16^{\mathrm{a}}$ \\
\hline & \multirow[b]{2}{*}{ Winter } & $7.52 \pm 1.33^{\mathrm{b}}$ & $\begin{array}{c}(202.88-209.64) \\
234.60 \pm 12.11^{\mathrm{a}}\end{array}$ & $\begin{array}{c}(33.28-36.78) \\
56.12 \pm 0.79^{\mathrm{b}}\end{array}$ & $\left.84.42+0.25^{\mathrm{b}}\right)$ & $\begin{array}{l}(4.29-4.85) \\
3.24+0.20^{\mathrm{b}}\end{array}$ \\
\hline & & $(5.07-9.65)$ & $(213.39-255.33)$ & $(54.96-57.63)$ & $(84.05-84.96)$ & $(3-3.65)$ \\
\hline & \multirow{2}{*}{ Spring } & $8.19 \pm 0.36^{b}$ & $92.28 \pm 1.18^{\mathrm{b}}$ & $32.52 \pm 0.58^{\mathrm{ab}}$ & $61.00 \pm 1.37^{\circ}$ & $4.44 \pm 0.10^{\mathrm{a}}$ \\
\hline & & $(7.55-8.78)$ & $(90.21-94.28)$ & $(31.6-33.59)$ & $(58.3-62.72)$ & $(4.29-4.69)$ \\
\hline & \multirow{2}{*}{ Summer } & $2.29 \pm 0.20^{\mathrm{c}}$ & $173.46 \pm 6.58^{\mathrm{a}}$ & $68.76 \pm 0.79^{c}$ & $122.25 \pm 2.14^{\mathrm{a}}$ & $6.31 \pm 0.16^{\mathrm{c}}$ \\
\hline & & $(1.98-2.67)$ & $(160.41-181.45)$ & $(67.63-70.28)$ & $(118.18-125.4)$ & $(6.11-6.62)$ \\
\hline \multirow{8}{*}{ Site 2} & \multirow{2}{*}{ Autumn } & $9.13 \pm 0.39^{\mathrm{a}}$ & $170.87 \pm 8.87^{\mathrm{a}}$ & $73.33 \pm 2.47^{\mathrm{a}}$ & $104.49 \pm 1.66^{\mathrm{a}}$ & $3.07 \pm 0.03^{a}$ \\
\hline & & $(8.36-9.66)$ & $(157.35-184.58)$ & $(70.39-78.25)$ & $(101.22-106.6)$ & $(3.02-3.11)$ \\
\hline & \multirow{2}{*}{ Winter } & $22.93 \pm 1.03^{b}$ & $390.22 \pm 12.56^{\mathrm{b}}$ & $68.77 \pm 1.26^{\mathrm{b}}$ & $102.22 \pm 0.33^{\mathrm{a}}$ & $3.43 \pm 0.12^{a}$ \\
\hline & & $(21.68-24.9)$ & $(365.29-405.37)$ & $(66.35-70.57)$ & $(101.81-102.8)$ & $(3.25-3.66)$ \\
\hline & \multirow{2}{*}{ Spring } & $35.69 \pm 1.51^{\mathrm{c}}$ & $70.84 \pm 1.71^{\mathrm{a}}$ & $5.48 \pm 0.17^{\mathrm{a}}$ & $123.87 \pm 3.26^{\mathrm{a}}$ & $4.32 \pm 0.03^{b}$ \\
\hline & & $(32.7-37.63)$ & $(68.54-74.18)$ & $(5.31-5.81)$ & $(118.36-129.6)$ & $(4.25-4.36)$ \\
\hline & \multirow{2}{*}{ Summer } & $11.49 \pm 0.45^{\mathrm{a}}$ & $67.17 \pm 0.07^{\mathrm{a}}$ & $20.4 \pm 0.98^{\mathrm{ab}}$ & $166.48 \pm 0.79^{\mathrm{b}}$ & $4.03 \pm 0.03^{\mathrm{ab}}$ \\
\hline & & $(10.85-12.3)$ & $(67.03-68.27)$ & $(19.37-22.36)$ & $(165.22-167.9)$ & $(3.99-4.09)$ \\
\hline
\end{tabular}

Table 2. Seasonal variations of heavy metal concentrations in mussels, Mytilus galloprovincialis, from Industrial gulf of Arzew (S1) and Bay of Oued Elma Kristel (S2). Results are expressed as seasonal mean \pm SE ( $\mathrm{n}=10)$; limit values of seasonal means are in brackets $(n=10)$ for each parameter; different letters $(a-c)$ indicate significant differences (Tukey's test. $\mathrm{p}<005$ ) among seasons for each sites (values in $\mathrm{mg} / \mathrm{kg}$ dry weight). 
to follow in parallel the breeding period of Mytilus galloprovincialis mussel with some modifications. They add that after their spawning period between summer and fall, mussels need energy that they capture from abiotic environmental factors (such as temperature, salinity and food availability) affecting the bioavailability of metals in its tissues.

These researchers confirm the results already cited in the work of Adami et al. (2002) and those of Soto et al. (2000) who mention that there is a significant bioaccumulation of metals during cold seasons in parallel with the reproduction of this species. According to Muduli \& Nayak (2018), agricultural activities, food waste and antifouling paints are the main sources of metallic pollution of the atmosphere by zinc and can be the source of zinc excretion by mussels once contaminated (Muduli \& Nayak, 2018). This confirms the results revealed by the work of Mejdoub et al. (2018) and those of Soto et al. (2000) concerning the bioaccumulation of zinc by the mussel and its excretion six months after being separated from a polluted zone to another unpolluted.

During the summer season, higher concentrations of Ni were observed in mussels at the S1 site with (68.76 \pm 0.79 mg. $\mathrm{kg}^{-1}$ dry weight, $\mathrm{p}<0.05$ ) compared to other seasons of the year. The same results were found by Abderrahmani et al. (2020) in the central Algerian coast. However, the concentration of $\mathrm{Ni}$ in the mussels sampled from the S2 site increases in the fall and decreases in the spring $(73.33 \pm 477$ and $5.48 \pm 0.17 \mathrm{mg} . \mathrm{kg}^{-1} \mathrm{dry}$ weight; $\mathrm{p}<0.05$, respectively).

The increase in Nickel at site $\mathrm{S} 1$ is probably due to the discharge of heavy hydrocarbons (Amiard et al., 2004), adding the cleaning and lubrication of certain equipment during the summer season. The high nickel contamination at site S2 may be caused by the use of fertilizers during the fall (Sreedevi et al., 1992).

In the case of Iron, the highest values are obtained during the summer $\left(122.25 \pm 2.14 \mathrm{mg} \cdot \mathrm{kg}^{-1}\right.$ dry weight, $\mathrm{p}<0.05$ ) in the S1 site mussels. On the other hand, in the $\mathrm{S} 2$ site, Iron concentrations reached their maximum value in summer (166.48 \pm 0.79 mg.kg ${ }^{-1}$ dry weight, $\mathrm{p}<0.05)$ and the lowest were recorded in winter $\left(102.22 \pm 0.33 \mathrm{mg} \cdot \mathrm{kg}^{-1}\right.$ dry weight, $\left.\mathrm{p}<0.05\right)$.

Notwithstanding, the iron concentrations recorded in Mytilus galloprovincialis appear to be higher during the summer season. This may be due to the intense influx of urban and industrial activities during the drought (Mejdoub et al., 2018). This same result was observed at the Saronikos golf course in Greece (Vlahogianni et al., 2007).
Ugur et al. (2002) pointed out that iron has a natural environmental origin; it provides oxygen to the lungs of the human body (Muduli \& Nayak, 2018). According to Roméo et al. (2005) and Chafik et al. (2001), the low concentrations of iron and manganese recorded in the tissues of Mytilus galloprovincialis reveal a lesser effect of the terrigenous particles rich in these elements.

Finally, the concentration of $\mathrm{Cu}$ at the $\mathrm{S} 1$ site reaches the highest level in the summer $(6.31 \pm 0.16$ mg. $\mathrm{kg}^{-1}$ dry weight, $\left.\mathrm{p}<0.05\right)$ and in the spring at the S2 site mussels $\left(4.32 \pm 0.03 \mathrm{mg} \cdot \mathrm{kg}^{-1}\right.$ dry weight, $\mathrm{p}<0.05$ ). Copper can come from agriculture because many plantations and vineyards are sown near the Kristel site (S2) where the mussels were sampled (Roméo et al., 2005).

Seasonal variations are related to the hydrological parameters (temperature and salinity) of the marine environment and physiological changes that control the reproductive activity of the species (Maanan, 2008; Saha et al., 2006; Szefer et al., 2004).

Compared to the literature, we take note that the mean annual concentrations of the two metals $(\mathrm{Pb}$, $\mathrm{Ni}$ ) recorded in the mussel tissues of this study greatly exceed the levels observed elsewhere (Table 5). Otherwise, the recorded concentrations of $\mathrm{Fe}$ and $\mathrm{Cu}$ in our mussel samples were lower than obtained in other parts of the Mediterranean. Zinc concentrations are significantly higher than those reported by other authors for the same region in Table 3 (Guendouzi et al., 2018; Rouane-Hacene et al., 2015).

As a result, the concentration of heavy metals in mussel tissues reflects environmental levels ( Fang et al., 2003; Spada et al., 2013). In addition, the mussels are at the same time bioindicating species of contamination and pose great public health problems. Whether wild or cultivated, they are ingested by man as seafood (Annicchiarico et al., 2010).

\section{Metallic indices in mussels Mytilus gallop- rovincialis}

The annual evolutions of the Mytilus galloprovincialis metal index of the two sites (S1 and S2) are illustrated in Fig. 3. A low metallic index is noted, regardless of the metal found in the tissues of the S2 site specimens. Regardless of the site, the decay of the indices sequence is noted as follows: $\mathrm{Zn} /$ shell-weight $>\mathrm{Fe} /$ shell-weight $>\mathrm{Ni} /$ shellweight $>\mathrm{Pb}$ / shell-weight $>\mathrm{Cu} /$ shell-weight. Significant differences were observed between seasons regardless of site (Table 4). 


\begin{tabular}{|c|c|c|c|c|c|c|}
\hline Location & $\mathbf{P b}$ & $\mathbf{Z n}$ & Ni & $\mathbf{F e}$ & $\mathrm{Cu}$ & References \\
\hline Marmara Sea & 1.36 & 264.13 & - & - & 7.66 & (Topcuoğlu et al., 2004) \\
\hline Izmir Bay (Aegean Sea) & 0.24 & 27.70 & - & - & 4.48 & (Kucuksezgin et al., 2002) \\
\hline $\begin{array}{c}\text { Balearic Islands (Western } \\
\text { Mediterranean) }\end{array}$ & 2.48 & 234.16 & - & - & 4.76 & (Deudero et al., 2009) \\
\hline Saronikos gulf Greece & - & 269 & 4.9 & 593 & 20.0 & (Strogyloudi et al., 2012) \\
\hline $\begin{array}{c}\text { Apulian Coasts (Adriatic } \\
\text { Sea) }\end{array}$ & 1.50 & 75.27 & - & - & 8.17 & (Spada et al., 2013) \\
\hline Algerian west coast & 7.49 & 87.98 & - & - & 5.22 & (Rouane-Hacene et al., 2015) \\
\hline Island of Sylt. Germany & 1.201 & 73.43 & 2.007 & - & 8.272 & (Helmholz et al., 2016) \\
\hline Western Mediterranean Sea & 7.41 & 24.26 & - & - & 7.54 & (Guendouzi et al., 2018) \\
\hline Casablanca coast & 7.66 & 414.39 & 4.5 & - & 17.94 & (Mejdoub et al., 2018) \\
\hline Cala Iris Sea & - & 162.2 & 3.102 & 529.47 & 5.794 & (Azizi et al., 2018) \\
\hline $\begin{array}{c}\text { Gulf of Arzew (Algerian } \\
\text { west coast) }\end{array}$ & 13.86 & 175.85 & 45.09 & 110.42 & 4.18 & Present study \\
\hline
\end{tabular}

Table 3. Heavy metals concentration in Mytilus galloprovincialis attained in various monitoring research (values in $\mathrm{mg} \cdot \mathrm{kg}^{-1}$ dry weight).

\begin{tabular}{|c|c|c|c|c|c|c|}
\hline Sites & Seasons & Index $\mathrm{Pb}$ & Index Zn & Index Ni & Index Fe & Index $\mathrm{Cu}$ \\
\hline \multirow{7}{*}{ Site 1} & Autumn & $0.97 \pm 0.42^{\mathrm{a}}$ & $18.31 \pm 9.60^{\mathrm{a}}$ & $1.32 \pm 0.79^{\mathrm{a}}$ & $7.64 \pm 5.11^{\mathrm{a}}$ & $0.56 \pm 0.12^{a}$ \\
\hline & \multirow{2}{*}{ Winter } & $\begin{array}{c}(0.15-1.56) \\
0.30 \pm 0.08^{\mathrm{b}}\end{array}$ & $\begin{array}{l}(2.56-35.7) \\
8.41 \pm 2.68^{\mathrm{b}}\end{array}$ & $\begin{array}{l}(0.43-2.9) \\
1.79 \pm 0.15^{\mathrm{b}}\end{array}$ & $\begin{array}{c}(1.23-17.76) \\
4.51 \pm 1.12^{\mathrm{b}}\end{array}$ & $\begin{array}{c}(0.35-0.79) \\
0.19 \pm 0.04^{b}\end{array}$ \\
\hline & & $(0.13-0.41)$ & $(4.03-13.29)$ & $(1.56-2.09)$ & $(2.3-6.01)$ & $(0.11-0.27)$ \\
\hline & \multirow{2}{*}{ Spring } & $0.64 \pm 0.03^{c}$ & $5.80 \pm 1.33^{\mathrm{b}}$ & $1.72 \pm 0.53^{\mathrm{b}}$ & $3.7 \pm 1.07^{\mathrm{b}}$ & $0.22 \pm 0.04^{b}$ \\
\hline & & $(0.57-0.69)$ & $(3.36-7.79)$ & $(0.83-2.67)$ & $(1.77-5.49)$ & $(0.16-0.30)$ \\
\hline & \multirow{2}{*}{ Summer } & $0.1 \pm 0.005^{\mathrm{d}}$ & $12.92 \pm 3.58^{\mathrm{ab}}$ & $2.79 \pm 0.73^{c}$ & $4.45 \pm 1.11^{b}$ & $0.31 \pm 0.02^{a b}$ \\
\hline & & $(0.9-0.11)$ & $(6.8-19.22)$ & $(1.36-3.79)$ & $(2.53-6.39)$ & $(0.27-0.34)$ \\
\hline \multirow{8}{*}{ Site 2} & \multirow{2}{*}{ Autumn } & $0.53 \pm 0.02^{\mathrm{a}}$ & $10.14 \pm 1.23^{\mathrm{a}}$ & $3.61 \pm 0.20^{\mathrm{a}}$ & $5.23 \pm 0.59^{a}$ & $0.16 \pm 0.01^{\mathrm{a}}$ \\
\hline & & $(0.5-0.58)$ & $(7.72-11.76)$ & $(3.2-3.84)$ & $(4.53-6.42)$ & $(0.14-0.19)$ \\
\hline & \multirow{2}{*}{ Winter } & $0.89 \pm 0.08^{b}$ & $16.30 \pm 0.16^{\mathrm{b}}$ & $2.38 \pm 0.23^{\mathrm{b}}$ & $3.77 \pm 0.41^{b}$ & $0.11 \pm 0.02^{\mathrm{a}}$ \\
\hline & & $(0.74-1.02)$ & $(16.01-16.57)$ & $(2.04-2.83)$ & $(2.95-4.2)$ & $(0.10-0.13)$ \\
\hline & \multirow{2}{*}{ Spring } & $1.17 \pm 0.05^{\mathrm{c}}$ & $2.49 \pm 0.21^{\mathrm{ac}}$ & $0.16 \pm 0.02^{\mathrm{a}}$ & $3.79 \pm 0.47^{b}$ & $0.13 \pm 0.02^{\mathrm{a}}$ \\
\hline & & $(1.06-1.24)$ & $(2.24-2.93)$ & $(0.11-0.19)$ & $(2.85-4.37)$ & $(0.09-0.16)$ \\
\hline & \multirow{2}{*}{ Summer } & $0.30 \pm 0.06^{\mathrm{a}}$ & $2.19 \pm 0.46^{\mathrm{ac}}$ & $0.60 \pm 0.07^{\mathrm{ab}}$ & $6.61 \pm 0.41^{\mathrm{c}}$ & $0.11 \pm 0.02^{a}$ \\
\hline & & $(0.22-0.44)$ & $(1.33-2.92)$ & $(0.46-0.68)$ & $(5.82-7.21)$ & $(0.07-0.14)$ \\
\hline
\end{tabular}

Table 4. Seasonal variations of metal/shell-weight indices in mussels, Mytilus galloprovincialis, from Industrial gulf of Arzew (S1) and Bay of Oued Elma Kristel (S2). Results are expressed as seasonal mean \pm SE ( $\mathrm{n}=10)$; limit values of seasonal means are in brackets $(n=10)$; for each parameter. different letters $(a-d)$ indicate significant differences (Tukey's test. $\mathrm{p}<005$ ) among seasons for each site (values in $\mathrm{mg} / \mathrm{kg}$ dry shell weight).

The metal index of zinc obtained at the S1 site was significantly higher $(\mathrm{p}<0.05)$ in autumn (18.31 \pm 9.60 mg. $\mathrm{kg}^{-1}$ dry shell weight) and in summer (12.92 $\pm 3.58 \mathrm{mg} \cdot \mathrm{kg}^{-1}$ dry shell weight). In site $\mathrm{S} 2$, the lowest level $\left(2.19 \pm 0.46 \mathrm{mg} \cdot \mathrm{kg}^{-1}\right.$ dry shell weight) was obtained in summer.

The metal index of iron in the mussels collected in site S1 reached the highest level in au- tumn $\left(7.64 \pm 5,11 \mathrm{mg} \cdot \mathrm{kg}^{-1}\right.$ dry shell weight, $\mathrm{p}$ $<0.05)$ and the highest low in the spring $(3.7 \pm 1.07$ $\mathrm{mg} . \mathrm{kg}^{-1}$ dry shell weight, $\left.\mathrm{p}<0.05\right)$. This index decreased significantly $(\mathrm{p}<0.05)$ at $\mathrm{S} 2(3.77 \pm 0.41$ $\mathrm{mg} . \mathrm{kg}^{-1}$ dry weight shell) in winter and increased in summer $\left(6.61 \pm 0.41 \mathrm{mg} . \mathrm{kg}^{-}{ }^{1}\right.$ dry shell weight).

The metal index of nickel at the S1 site is significantly more dominant $(p<0.05)$ during the 


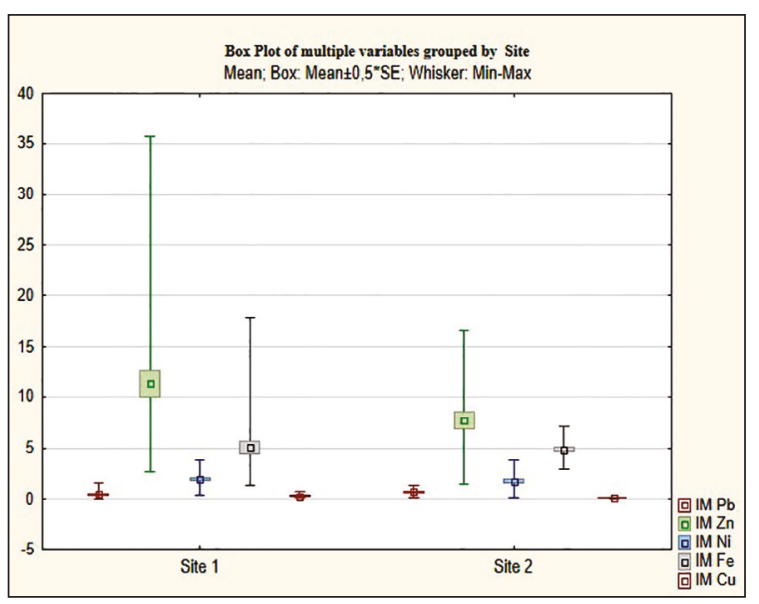

Figure 3. Annual variations of metal/shell-weight indices in mussels, Mytilus galloprovincialis, from Industrial gulf of Arzew (S1) and Bay of Oued Elma Kristel (S2).

summer (2.79 $\pm 0.73 \mathrm{mg} \cdot \mathrm{kg}^{-1}$ dry shell weight) than during the other seasons. This index decreased considerably $(\mathrm{p}<0.05)$ in the spring $(0.16 \pm 0.02 \mathrm{mg} . \mathrm{kg}$ ${ }^{1}$ dry shell weight $)$ and in summer $(0.60 \pm 0.07 \mathrm{mg} . \mathrm{kg}-$ ${ }^{1}$ dry shell weight) at site S2.

The metal index of lead reached the highest level $(\mathrm{p}<0.05)$ in autumn $\left(0.97 \pm 0.42 \mathrm{mg} \cdot \mathrm{kg}^{-1}\right.$ dry shell weight) and the lowest $(\mathrm{p}<0.05)$ in summer $\left(0.1 \pm 0.005 \mathrm{mg} . \mathrm{kg}^{-1}\right.$ dry shell weight $)$ at site $\mathrm{S} 1$. On the other hand, we observed at site S2 a higher level $(\mathrm{p}<0.05)$ in winter $\left(0.89 \pm 0.08 \mathrm{mg} . \mathrm{kg}^{-1}\right.$ dry shell weight) and the lowest level $(p<0.05)$ in summer.

The metal index of copper is significantly higher $(p<0.05)$ in autumn and has a lower value $(p<0.05)$ in summer at both sampling sites.

Metal indices indicate that the bioavailability of metals is very high and confirms that metal concentrations are relatively high in native mussel's tissue (Mejdoub et al., 2018). Fischer (1984) states that this index is the reliable tool for estimating the bioavailability of metals in the environment (Fischer, 1984).

The work of Bartolomé et al. (2010) state that the metal / shell weight index used to normalize the analytical concentration is useful for removing some of the variability due to the inherent biology of sentinel mussels.

\section{CONCLUSIONS}

The evaluation of the bioaccumulation and bioavailability of metals $(\mathrm{Pb}, \mathrm{Zn}, \mathrm{Ni}, \mathrm{Fe}$ and $\mathrm{Cu})$ in the soft tissues of Mytilus galloprovincialis collected on the Algerian occidental coasts revealed the true state of contamination of the aquatic environment.

The present study records a strong contamination of both sites. The main cause of this contamination at site 1 is the very important industrialization, the petrochemical installations, an active port and many industrial and domestic discharges. The pollution recorded at site 2 is probably due by agricultural activities and pesticides used, adding the discharges of urban domestic water.

Thus, the presence of metals in mussel's tissue reflects environmental levels contaminated. In addition, mussels (both cultivated and wild) are served as bioindicative of pollution and raise public health concerns when consumed as seafood. The consumption of bivalves could have negative effects on human health in general and on children in particular. Periodic monitoring and control of trace metals in commercial mussels is required for assessments of the safety and quality of water in the environment.

Similar studies can be done with more mussels samples to confirm the trend noted in this study. Awareness campaigns should be conducted to inform the public of the risk of toxicity of metals.

\section{REFERENCES}

Abderrahmani, K., Boulahdid, M., Bendou, N. \& Aissani, A., 2020. Seasonal distribution of cadmium, lead, nickel, and magnesium in several tissues of mussels from the Algerian coasts. Environmental Science and Pollution Research. 27: 22547-22567. https://doi.org/10.1007/s11356-020-08682-8

Adami G., Barbieri P., Fabiani M., Piselli S., Predonzani S. \& Reisenhofer E., 2002. Levels of cadmium and zinc in hepatopancreas of reared Mytilus galloprovincialis from the Gulf of Trieste (Italy). Chemosphere, 48: 671-677. https://doi.org/10.1016/S0045-6535(02)00196-0

Aminot A. \& Chaussepied M., 1983. Manual for Chemical Analyses in Marine Environment. Publications of the National Center for Exhibition. Oceans Oceanographic Center of Brittany, Brest, 395 pp.

Andral B., Galgani F., Tomasino C., Bouchoucha M., Blottiere C., Scarpato A., Benedicto J., Deudero S., Calvo M., Cento A., Benbrahim S., Boulahdid M. \& Sammari C., 2011. Chemical Contamination Baseline in the Western Basin of the Mediterranean Sea Based on Transplanted Mussels. Archives of Environmental Contamination and Toxicology, 61: 261-271. https://doi.org/10.1007/s00244-010-9599-x

Andral B., Stanisiere J.Y., Sauzade D., Damier E., Thebault H., Galgani F. \& Boissery P., 2004. Monitoring chemical contamination levels in the Mediterranean 
based on the use of mussel caging. Marine Pollution Bulletin, 49: 704-712. https://doi.org/10.1016/j.marpolbul.2004.05.008

Annicchiarico C., Assennato G., Blonda M., Cardellicchio N., Di Leo A., Giandomenico S., Lopez L., Spada L. \& Ungaro N., 2010. Preliminary results of pollutants biomonitoring in coastal marine and transitional waters of Apulia region (Southern Italy). Fresenius Environmental Bulletin, 19: 1841-1847.

Azizi G., Layachi M., Akodad M., Yáñez-Ruiz D.R., Martín-García A.I., Baghour M., Mesfioui A., Skalli A. \& Moumen, A., 2018. Seasonal variations of heavy metals content in mussels (Mytilus galloprovincialis) from Cala Iris offshore (Northern Morocco). Marine Pollution Bulletin, 137: 688-694. https://doi.org/10.1016/j.marpolbul.2018.06.052

Bartolomé L., Navarro P., Raposo J.C., Arana G., Zuloaga O., Etxebarria N. \& Soto M., 2010. Occurrence and Distribution of Metals in Mussels from the Cantabrian Coast. Archives of Environmental Contamination and Toxicology, 59: 235-243. https://doi.org/10.1007/s00244-010-9476-7

Benali I., Boutiba Z., Merabet A. \& Chèvre N., 2015. Integrated use of biomarkers and condition indices in mussels (Mytilus galloprovincialis) for monitoring pollution and development of biomarker index to assess the potential toxic of coastal sites. Marine Pollution Bulletin, 95: 385-394. https://doi.org/10.1016/j.marpolbul.2015.03.041

Borghini M., Bryden H., Schroeder K., Sparnocchia S. \& Vetrano A., 2014. The Mediterranean is becoming saltier. Ocean Science, 10: 693-700. https://doi.org/10.5194/os-10-693-2014

Cantillo A.Y., 1998. Comparison of results of Mussel Watch Programs of the United States and France with Worldwide Mussel Watch Studies. Marine Pollution Bulletin, 36: 712-717. https://doi.org/10.1016/S0025-326X(98)00049-6

Bliefert C. \& Perraud R., 2001. Chimie de l'environnement. De Boeck Superieur, 478 pp.

Chafik A., Cheggour M., Cossa D. \& Sifeddine S.B.M., 2001. Quality of Moroccan Atlantic coastal waters: water monitoring and mussel watching. Aquatic Living Resources, 14: 239-249. https://doi.org/10.1016/S0990-7440(01)01123-8

Dang D.H., Schäfer J., Brach-Papa C., Lenoble V., Durrieu G., Dutruch L., Chiffoleau J.-F., Gonzalez J.-L., Blanc G., Mullot J.-U., Mounier S. \& Garnier C., 2015. Evidencing the Impact of Coastal Contaminated Sediments on Mussels Through Pb Stable Isotopes Composition. Environmental Science \& Technology, 49: $11438-11448$. https://doi.org/10.1021/acs.est.5b01893

Deudero S., Box A., Tejada S. \& Tintoré J., 2009. Stable isotopes and metal contamination in caged marine mussel Mytilus galloprovincialis. Marine Pollution Bulletin, 58: 1025-1031. https://doi.org/10.1016/j.marpolbul.2009.02.011
Fang Z.-Q., Cheung R.Y.H. \& Wong M.H., 2003. Heavy metals in oysters, mussels and clams collected from coastal sites along the Pearl River Delta, South China. Journal of Environmental Science China, 15: 9-24.

Fischer H., 1984. Cadmium body burden/shell weight of mussels: a precise index for environmental monitoring, in: International Council for the Exploration of the Sea Council Meeting Documents, CMCESRE, pp. 1-19.

Fowler S.W., 2002. A Mediterranean Mussel Watch for radionuclides: what is the best information that can be gained? In: CIESM Workshop Series, pp. 67-70.

Goldberg E.D., Koide M., Hodge V., Flegal A.R. \& Martin J., 1983. U.S. Mussel Watch: 1977-1978 results on trace metals and radionuclides. Estuarine, Coastal and Shelf Science, 16: 69-93. https://doi.org/10.1016/0272-7714(83)90095-1

González-Fernández, C., Albentosa, M., Campillo, J.A., Viñas, L., Fumega, J., Franco, A., Besada, V., González-Quijano, A., Bellas, J., 2015. Influence of mussel biological variability on pollution biomarkers. Environmental Research, 137: 14-31. https://doi.org/10.1016/j.envres.2014.11.015

Guendouzi Y., Soualili D.L., Boulahdid M. \& Boudjellal B., 2018. Biological Indices and Monitoring of Trace Metals in the Mussel from the Southwestern Mediterranean (Algeria): Seasonal and Geographical Variations. Thalassas, Journal of Marine Science, 34: 103112. https://doi.org/10.1007/s41208-017-0043-0

Hachemi T. \& Chafika H., 2019. Use of the Mussel Mytilus Galloprovincialis in Monitoring Heavy Metal Levels in Seawater from Western Algerian coast. Colloque national sur la sécurité des procédés et le développement durable (CNSPDD'19). Oral communications, p. 31.

Hadj Z.E., Boutiba Z. \& Belbachir B., 2012. Mytilus galloprovincialis; as Mussel Watch for Butyltins, Tin, Copper and Zinc Contamination, from Antifouling Paint Particles, in West Algerian Coastal Waters. Journal of Environmental Protection, 3: 1047-1053. https://doi.org/10.4236/jep.2012.39122

Helmholz H., Ruhnau C., Pröfrock D., Erbslöh H.-B. \& Prange A., 2016. Seasonal and annual variations in physiological and biochemical responses from transplanted marine bioindicator species Mytilus spp. during a long term field exposure experiment. Science of the Total Environment, 565: 626-636. https://doi.org/10.1016/j.scitotenv.2016.04.202

IBGE, 2005. Qualité physico chimique et chimie des eaux : cadre général. Institut Bruxellois pour la gestion de l'Environnement. Belgique, $16 \mathrm{pp}$.

Iorga M. \& Lozier M., 1999. Signatures of the Mediterranean outflow from a North Atlantic climatology: 1. Salinity and density fields. Journal of Geophysical Research Oceans, 104: 985-26. https://doi.org/10.1029/1999JC900115

Kucuksezgin F., Uluturhan E., Kontas A. \& Altay O., 2002. Trace metal concentrations in edible fishes from Izmir Bay, Eastern Aegean. Marine Pollution Bulletin, 44: 827-832. https://doi.org/10.1016/S0025-326X(02)00110-8 
Maanan M., 2008. Heavy metal concentrations in marine molluscs from the Moroccan coastal region. Environ. Pollut., Chelating Agents in the Environment, 153: 176-183. https://doi.org/10.1016/j.envpol.2007.07.024

Martínez-Gómez C., Fernández B., Robinson C.D., Campillo J.A., León V.M., Benedicto, J., Hylland K. \& Vethaak A.D., 2017. Assessing environmental quality status by integrating chemical and biological effect data: The Cartagena coastal zone as a case. Marine Environmental Research, 124: 106-117. https://doi.org/10.1016/j.marenvres.2016.04.008

Mejdoub Z., Zaid Y., Hmimid F. \& Kabine M., 2018. Assessment of metals bioaccumulation and bioavailability in mussels Mytilus galloprovincialis exposed to outfalls pollution in coastal areas of Casablanca. Journal of Trace Elements in Medicine and Biology, 48: $30-37$. https://doi.org/10.1016/j.jtemb.2018.02.018

Muduli S. \& Nayak L., 2018. Comparitive study on iron, copper, zinc and lead metals in two commercially important shrimps Penaeus Monodon and Penaeus Indicus. International Journal of Advance Research and Innovation, 1: 8-12.

Neff J.M., 2002. Bioaccumulation in Marine Organisms: Effect of Contaminants from Oil Well Produced Water. Elsevier.

Roméo M., Frasila C., Gnassia-Barelli M., Damiens G., Micu D. \& Mustata G., 2005. Biomonitoring of trace metals in the Black Sea (Romania) using mussels Mytilus galloprovincialis. Water Research, 39: 596604. https://doi.org/10.1016/j.watres.2004.09.026

Rouane-Hacene O., Boutiba Z., Belhaouari B., Guibbolini-Sabatier M.E., Francour P. \& Risso-de Faverney C., 2015. Seasonal assessment of biological indices, bioaccumulation and bioavailability of heavy metals in mussels Mytilus galloprovincialis from Algerian west coast, applied to environmental monitoring. Oceanologia, 57: 362-374. https://doi.org/10.1016/j.oceano.2015.07.004

Saha M., Sarkar S.K. \& Bhattacharya B., 2006. Interspecific variation in heavy metal body concentrations in biota of Sunderban mangrove wetland, northeast India. Environment International, 32: 203-207. https://doi.org/10.1016/j.envint.2005.08.012

Soto M., Ireland M.P. \& Marigómez I., 2000. Changes in mussel biometry on exposure to metals: implications in estimation of metal bioavailability in 'Mussel-Watch' programmes. Science of the Total Environment, 247: 175-187. https://doi.org/10.1016/S0048-9697(99)00489-1

Soto M., Ireland M.P. \& Marigómez I., 1997. The contribution of metal/shell-weight index in target-tissues to metal body burden in sentinel marine molluscs. 2 . Mytilus galloprovincialis. Science of the Total Environment, 198: 149-160. https://doi.org/10.1016/S0048-9697(97)05451-X

Spada L., Annicchiarico C., Cardellicchio N., Giandomenico S. \& Di Leo A., 2013. Heavy metals monitoring in mussels Mytilus galloprovincialis from the Apulian coasts (Southern Italy). Mediterranean Marine Science, 14: 99. https://doi.org/10.12681/mms.323

Sreedevi, P., Suresh, A., Sivaramakrishna, B., Prabhavathi, B., Radhakrishnaiah, K., 1992. Bioaccumulation of nickel in the organs of the freshwater fish, Cyprinus carpio, and the freshwater mussel, $\mathrm{La}$ mellidens marginalis, under lethal and sublethal nickel stress. Chemosphere, 24: 29-36. https://doi.org/10.1016/0045-6535(92)90564-8

Strogyloudi E., Angelidis M., Christides A. \& Papathanassiou E., 2012. Metal concentrations and metallothionein levels in Mytilus galloprovincialis from Elefsis bay (Saronikos gulf, Greece). Environmental Monitoring and Assessment, 184: 7189-7205. https://doi.org/10.1007/s10661-011-2490-z

Szefer P., Kim B.-S., Kim C.-K., Kim E.-H. \& Lee C.-B., 2004. Distribution and coassociations of trace elements in soft tissue and byssus of Mytilus galloprovincialis relative to the surrounding seawater and suspended matter of the southern part of the Korean Peninsula. Environmental Pollution, 129: 209-228. https://doi.org/10.1016/j.envpol.2003.10.012

Taleb Z. \& Boutiba Z., 2007. La moule Mytilus galloprovincialis: Bioindicatrice de pollution marine - cas du port d'Oran. Science and Technology, 25: 59-64.

Thebault H., Baena A., Andral B., Barisic D., Albaladejo J., Bologa A., Boudjenoun R., Delfanti R., Egorov V., Khoukhi T., Florou H., Kniewald G., Noureddine A., Patrascu V., Pham M., Scarpato A., Stokozov N., Topcuoglu S. \& Warnau M., 2008. Cs-137 baseline levels in the Mediterranean and Black Sea: A cross-basin survey of the CIESM Mediterranean Mussel Watch programme. Marine Pollution Bulletin, 57: 801-806. https://doi.org/10.1016/j.marpolbul.2007.11.010

Topcuoğlu S., Kirbaşoğlu Ç. \& Yilmaz Y.Z., 2004. Heavy Metal Levels in Biota and Sediments in the Northern Coast of the Marmara Sea. Environmental Monitoring and Assessment, 96: 183-189. https://doi.org/10.1023/B:EMAS.0000031726.01364.47 Uğur A., Yener G. \& Başsarı A., 2002. Trace metals and $210 \mathrm{Po}(210 \mathrm{~Pb})$ concentrations in mussels (Mytilus galloprovincialis) consumed at western Anatolia. Applied Radiation and Isotopes, 57: 565-571. https://doi.org/10.1016/S0969-8043(02)00141-0

Vlahogianni T., Dassenakis M., Scoullos M.J. \& Valavanidis A., 2007. Integrated use of biomarkers (superoxide dismutase, catalase and lipid peroxidation) in mussels Mytilus galloprovincialis for assessing heavy metals' pollution in coastal areas from the Saronikos Gulf of Greece. Marine Pollution Bulletin, 54: 13611371. https://doi.org/10.1016/j.marpolbul.2007.05.018

Wells D.E., 1994. QUASIMEME: Quality Assurance of Information for Marine Environmental Monitoring in Europe. Marine Pollution Bulletin, 29: 143-145. https://doi.org/10.1016/0025-326X(94)90406-5 
